\title{
GOD EMPEROR TRUMP: \\ DEFENDING WESTERN CIVILIZATION AGAINST NEO-MARXISM AND MILITANT ISLAM
}

\author{
ROBERT M. PRICE*
}

\begin{abstract}
As we await the Second Coming of President Donald Trump, it is important to understand that his conservative Evangelical supporters view him not as a new Christ but as a new Constantine, a guardian of Western Civilization in a crucial period when we face threatened conquest by foreign enemies and infiltrators, Postmodern Neo-Marxism, and Militant Islam Thus he should be seen also as a new Charles Martel. He need not be a Bible-reading pietist to fulfill these roles, so Christians need not be ashamed of him if he isn't.
\end{abstract}

KEY WORDS: Trump, Islam, religion, politics, Christianity

\section{The Religion of Trump}

Of the countless controversies surrounding the Presidency of Donald J. Trump, one of the most interesting to some of us is that of the President's personal faith and that of his supporters. It seems that few even among his Evangelical partisans believe that Donald Trump is personally pious. It is enough for them that he left behind certain immoral habits of his youthful days. It should be obvious that he has put behind him 'sinful' (left-leaning) political sympathies, so why should a new moral seriousness be any less plausible? But plausibility is not probability. Those who know President Trump personally could no doubt enlighten us, as if it were any of our business, but, short of that, it would take a telepath to unlock the secret of Trumpian faith, and those are in short supply.

But there are clues. Early on in the 2016 campaign, when the matter of his Christian identity came up, Trump replied that, yes, he is a Protestant. To me this signaled that he had only a superficial identification with his religious inheritance. In my long experience among Evangelicals, I have never heard anyone describe him or herself 'merely' as a Protestant rather than claiming a specific denominational tag: 'I'm a Lutheran', 'I'm a Baptist', 'a Pentecostal', 'a Presbyterian', etc. It denotes churchgoing: I attend this or that particular

* ROBERT M. PRICE (PhD 1993, Drew University) is a semi-retired scholar of religion, with doctorates in Theology and New Testament. 
congregation: Pillow Presbyterian, Mattress Methodist, Bedside Baptist, etc. Saying 'I'm a Protestant' is like saying, 'If I went to church, it wouldn't be a Catholic one.' Or, in other terms, 'I'm a Protestant' is like saying, 'I'm a North American.'

But there's nothing wrong with claiming a generic religious orientation even if it falls short of the vibrant personal faith prized by supporters like Jerry Falwell, Jr. And they do not hold it against him. As Mike Huckabee said in order to dispel the hesitations of fellow Evangelicals about voting for Mormon Mitt Romney during the 2012 election: 'I'm not voting for a Sunday School teacher; I'm voting for a President.' And, especially after an exasperating two terms of Barack Obama, the Evangelical mainstream appears to have gained a new political maturity, catching up with Huckabee.

But that's not all Evangelicals. Some rebuke their fellows for 'compromising' with a worldly politician, selling out the true Christian witness of groups like the Sojourners community and their precursors Evangelicals for McGovern. On one hand, one suspects a resurgence of the old fundamentalist separatism that once led some to condemn Jerry Falwell, Sr., as the Antichrist for inviting socio-politically conservative Jews, Roman Catholics, and Mormons to join as cobelligerents against liberalism in the Moral Majority. Falwell wasn't promoting ecumenical religious services or theological syncretism. Just common-sense political pragmatism. Is this separatism what we are now hearing from these Never-Trumper Evangelicals? Are their hands too pure to be defiled by shaking hands with the worldlings?

On the other hand, one cannot help suspecting that anti-Trump Evangelicals are themselves diluting their religion with secular politics. It seems plain that theological Liberalism has effectively merged with far-left secular Liberalism. To be a Christian, for them, is to fight Climate Change, to advocate Open Borders and Socialism. These are the essence of Christian discipleship, of Christianity itself. Though sitting loose generally to any 'biblical authority,' they are incongruously zealous to employ out-of-context proof texts that can be bent to a Leftist agenda. I think Politically 'Progressive' Evangelicals are nearly, if not completely, in the same place. They are, I think, diluting their avowed faith in the manner implied by C.S. Lewis's phrase 'Christianity and water.'

Conservative Evangelicals have too easily done the same thing, transforming Christianity into a species of Americanism. But just here I think the more clear-eyed Evangelical assessment of President Trump has helped them to avoid this pitfall. Evangelicals who want their President to be a fellow believer, a devout coreligionist, are in greater danger of succumbing to the theocratic temptation. But those Evangelicals who are under no illusion about Trump being a fellow Born Again Christian must view him as an ally, not a caliph. 
When President Trump announced the official recognition of Jerusalem as the capital of Israel, some rabbis are said to have declared him to be the Davidic Messiah. But his American Evangelicals seem to view him, I think, as more analogous to the Emperor Constantine. Though Constantine was in some sense a Christian, either raised as one (Elliott 2005) or subsequently converted, he was not any kind of traditional Christian. After all, he continued in office as the Pontifex Maximus of the state-sponsored cult of Sol Invictus. The Christians of his day blessed God for him, not because he enjoyed a 'heart-warming' personal relationship with Christ, but because he ended Rome's persecution of Christians and granted Christianity official legitimacy. As long as he did that, I'm guessing that little else mattered. That is Trump: he stood up to halt and reverse the Secular Progressive crusade against traditional Jewish and Christian values. It was part of his agenda of defending the freedoms enshrined in the Bill of Rights. Even his America First agenda can be understood in this way: only so can America remain the bastion of Western Civilization. We are threatened by anti-Western pressures from within and without, and Evangelicals see the 45th President as having 'come to the kingdom for such a time as this' (Esther 4:14). Again, he corresponds to the Persian Emperor Cyrus the Great who allowed God's people to leave Babylon and return to the Promised Land.

\section{A Theology of Trump}

On any reading, one of the great values of the Bible is its catalog of historical paradigms. As Rabbi Jacob Neusner has explained (Neusner 2000), there are many 'case studies' (as we might call them) that provide model scenarios that we may 'try on for size' in our own historical circumstances, in order to 'discern the signs of the times' (Matthew 16:3). It is notoriously hazardous to match biblical texts with current events if we see the parallels as prophetic predictions and their historical fulfillments. Such speculations are always ripe for embarrassment (Wilson 1977). But why are people so eager, so tempted, to venture such interpretations? Not because they are fanatics. True, they are jumping the gun, but they are seeing something real. The parallels do shed light on contemporary developments, suggesting appropriate responses. Did Hitler turn out to be the Antichrist? No, because the world did not end. But was he an Antichrist? Let's see: he persecuted the people of God unto the death. He engulfed the world in a Great Tribulation. He made a god of himself, and so on. Richard Wurmbrand, a Christian pastor, long a prisoner in a Communist country, told of a desperate message smuggled out of the USSR during Stalin's reign of iron-fisted terror: 'When did the Rapture occur?' (Richard Wurmbrand, speech delivered at Brookdale Baptist Church, Bloomfield, NJ, 1971). It seemed self-evident to them that the End Times had begun. Were they wrong? Yes and no. They were correctly discerning 
the signs of the times. They knew what sort of trial they had to endure: 'This calls for endurance on the part of the saints' (Revelation 14:12).

Suppose the government were to require all citizens to have a microchip implanted subcutaneously. It would contain all sorts of information available to doctors, employers, the police. It would contain your credit history and tell your moment-to-moment location. Some would proclaim it as the Mark of the Beast in Revelation 13, which it might conceivably be. But odds are that would be premature. It seems unlikely, given the poor batting average of such modern prophets, that there would be a one-to-one connection between the scriptural text and the microchip: 'This is that spoken by the prophet' (Acts 2:16). But it would be the same kind of thing. It would be close enough, too close for comfort. One ought to be concerned, even alarmed. One ought to think, 'Do I want to submit to that?' Maybe the 'real thing' would arrive one day. But in the meantime, is there some guidance here?

I see such a biblical paradigm in Donald Trump's mission to 'drain the swamp'. It provides a historical application of the biblical doctrine of the Principalities and Powers (Caird 1956; Montgomery 1975). We begin with the transition from Israelite polytheism to monotheism, a development I place (much later than most) in the mid-second century BCE, part of the vaunted Deuteronomic Reform (Price 2017: 167-168; Barker 2005: 96-97, 145, 191-192). What were they supposed to do with the seventy or so obsolete deities whom Jews had formerly worshipped? Well, first they said these were the sons of God, who appointed a fiefdom for each one to rule (Deuteronomy 32:8-9), to be in charge of answering prayers, defending his people in war, etc. But if there was now to be but a single God, these lesser beings had to be redefined, but how? When, centuries later, Christianity displaced pagan polytheism, Christians stigmatized Apollo, Mithras, and the rest as demons pure and simple, fallen angels who had rebelled against God, and with predictable results. The Deuteronomists took basically the same path, making the sons of God into fallen angels, too, but with a fascinating difference. These Fallen Ones still ruled their allotted nations. They were still (at least for the present) in charge-and, again, with predictable results. This was the Jewish explanation for evil and oppression in the world, much of the brunt of which Jews steadfastly bore.

But even when not suffering outright persecution by Gentile regimes, Jews maintained a fragile coexistence with the pagan authorities whose subjects they were. For instance, the Jewish priesthood collected Roman taxes at the Jerusalem Temple and even offered daily sacrifices on Caesar's behalf. It was the cessation of these offerings that brought on the Roman-Jewish War. This ongoing situation was expressed in the doctrine of the Principalities and Powers. Jews believed that the pagan empires were clients of the Fallen Angels (Daniel 10:13). The gospels depict demons as 'unclean spirits', roaming 
'lone wolf' devils afflicting random victims with insanity and epilepsy. But the epistles speak rather of the Big Bosses: the Powers behind the thrones of the nations.

Jews (and then Christians, too) believed that one day God would clean house, eject these Cosmic Gangsters, and assume direct control of the world (Psalm 82:6-8). But until then, let's face it, pagan rule was better than none at all. Would you rather have chaos? The War of All Against All? Modern Bible-derived mythology gives us a good illustration of the difference. You may have seen the three Omen movies in which Damien Thorn is groomed to become the Antichrist. His mission would be to achieve world dictatorship, controlling food supplies in order to force his subjects to worship him and his Father Below. Bad enough, you say? Once Damien is assassinated it only gets worse: in a sequel novel, Gordon McGill's Omen IV: Armageddon 2000, his son takes over, and he has no interest in ruling the world (McGill 1988). Instead he wants to destroy it! Even his Satanist acolytes oppose this plan.

This one is explained by Peter L. Berger and Thomas Luckmann in The Social Construction of Reality (Berger and Luckmann 1967: 58-59, 89; see also Berger 1969: 4). They outline the process by which the ingenious inventions of human beings like ourselves are subsequently elevated to the stature of divine creations with unimpeachable authority and majesty. In the beginning of a civilization the wise elders see the need for rules and laws in order to maximize peaceful coexistence. You have to eliminate as much theft, murder, rape, etc., as possible if you want a livable society (on an episode of the comedic television program Seinfeld an indignant George Costanza, refused the time requested from a passer-by, barks, 'You know, we're living in a society!'). Those who frame these laws and customs know good and well the ad hoc nature of their creations, but the next generation inherits these rules as a reality external to and prior to themselves. Thus the social arrangements appear with a new gravity they had not originally possessed. Perhaps they will even come to be deemed God's commandments.

What has happened here? Human beings become alienated from their inventions so that these become objectified, then reified. Reification means that arrangements designed by humans for humans are transformed into selfperpetuating realities served by humans. Jesus understood this when he said, 'The Sabbath was made for man, not man for the Sabbath' (Mark 2:27). This is why longstanding socio-political institutions are so intransigent, so resistant to change. The same priorities and patterns live on from one generation to another of the institution's leadership. Any individual who doesn't like it and tries to change things will not long survive. There is no single individual conscience for him to attempt to persuade. He squares off against a faceless machine. 'We wrestle not against flesh and blood but against the Principalities, against the Powers, against the world rulers of this present darkness, against 
the spiritual hosts of wickedness in the heavenly spheres' (Ephesians 6:12). Hendrikus Berkhof, in his classic monograph Christ and the Powers, showed how the early Christians, in their steadfast refusal to retain the mores and values of their pagan contemporaries in Roman societies were energized by their firm belief that, by his crucifixion by Temple and Imperial authorities, then being triumphantly resurrected by God, Christ had broken the back, called the bluff, of these institutions (metaphorically or metaphysically), as per Colossians 2:15 (Berkhof 1962). As Walter Rauschenbusch observed, it was such super-personal forces that colluded to put Jesus to death: religious bigotry, graft and political power, corruption of justice, mob spirit and mob action, militarism, and class contempt (Rauschenbusch 1945: 248-258). The institutional forces of this age had done their worst but to no avail. God would do the same for his faithful people.

When Donald Trump declared war on the Washington swamp of entrenched corruption, a Sargasso Sea of political paralysis overseen by an elite class of self-enriching bureaucrats looking out for their own interests and merely using the citizenry as tool to that end, millions of Americans saw him, with his unique combination of gifts and skills as their champion. If anyone stood to tell these modern American Principalities and Powers, 'You're fired!' it would be Donald Trump. To believe this of President Trump would not be to make a literally Messianic claim on his behalf, but it would be to apply an important and revelatory biblical paradigm to the prevailing situation.

To return to the Trump/Constantine parallel, I want to develop one more aspect of Peter Berger's analysis of society and what holds it together, namely the Sacred Canopy (Berger 1969: 33-39). The system of values, mores, beliefs, manners, and laws passed down from one generation to another does not only appeal to a divine origin for the sake of clout for the current rulers. ('Look, you're not just disobeying us; you're disobeying God.') No, once the social system is established, God functions as the capstone for the whole thing. Whether there actually is a divine Being or it is a convenient construct of the human imagination, 'God' is a name for the ultimacy of our most cherished values and customs. As Durkheim (in whose tradition Berger and Luckmann stand) said, it is not sufficient to say that God guarantees the preferred social arrangements (Durkheim 1965: 236-237). One can almost say that God is that arrangement. The worship of God is the sanctification of the way our community believes and lives. Again, this is not to reduce God to some sort of a legal fiction; it is simply an explanation of the important function of the belief in God.

The universal utility of this structure of belief is apparent even in the pluralistic society we now enjoy. We no longer share a single religion. Christians may still form the majority, but expressions of other faiths confront us every day in school classrooms, in offices, in convenience stores. But for decades we 
have filled the gap with Civil Religion (Richey and Jones 1974; Bellah 1980), an unofficial, non-theological second religion that all patriotic Americans may share. The Declaration of Independence, the Constitution, and the Bill of Rights are our common scriptures. July Fourth is our high holy day. The Founding Fathers are our Church Fathers. Abraham Lincoln is our martyred savior whose death redeemed the sundered Union. The Stars and Stripes are our holy icon, which explains the outrage at public flag burning. It is more than an act of protected political speech. It so offends us because we experience it as blasphemy. It seems obvious that Civil Religion, or Americanism, or Patriotism, is religious in character, not just analogous to a religion, but most Americans, I dare say, remain oblivious of the fact. Why? Because people do not think it allowable to hold two religions. Thus, we tacitly refuse to call one of them a religion.

But even this second religion is now in danger, and, with it, the cultural and moral solidarity of the nation. No authority is anymore sacred. As the Book of Judges says, 'every man did what was right in his own eyes.' There would be less danger in this if individuals had achieved emotional and intellectual maturity, if their opinions were not so often the product of cynical farleft educators and equally ignorant young peers. Society increasingly pulls apart, connective tissues of national loyalty fraying and snapping as 'identity' groups claim our primary loyalty. Aggressive secularism mounts fierce assaults on traditional religions, making a conspicuous exception for militant Islam which shares the 'virtue' of hating Western Civilization (Horowitz 2006). Secularists, such as the lawsuit-happy Freedom from Religion Foundation, have recognized what others have not: that Patriotic Americanism is a religion and thus the Secularists' enemy. Many of us see America sinking into the ocean of history, leaving behind small islands and atolls, each populated by groups of bitter, shouting ethnic, gender, and political zealots.

I understand our present epidemic of gender confusion as the manifestation of what Giles Deleuze and Felix Guattari (Deleuze and Guattari 2009) welcome and proclaim as the dawn of the Schizoid Man, a casting off of what neo-Freudian Jacques Lacan (see the discussion of Lacan versus DeLeuze and Guattari in Cupitt 1987) calls 'the Law of the Father', the identity definitions imposed on every child as part of the socialization process. Deleeuze and Guattari urge us to cast off the chains of that consistency that is the hobgoblin of little minds. Be all you can be, consistent or not. I see it as the psychological equivalent of what the radical philosopher of science Paul Feyerabend (Feyerabend 1988: 14) prescribes as the only principle that does not inhibit scientific research: 'Anything goes!' The postmodern person should not hesitate to 'be all over the place.' His proper name is Legion. It is a wild existential freedom that does not rein itself in by restrictive codes. 
Again, it is the individual/psychological version of the death of traditional Narratives that used to supply national and cultural identities, a cultural crisis discussed by Jean-Francois Lyotard (Lyotard 1984). This is what makes possible today's espousal of 'world citizenship,' open borders, and the disdain for nationalism and patriotism as mere jingoism. Personally, I believe that these trends, whatever may be said in their favor, are sowing the wind and will sooner or later lead to reaping the whirlwind. Even when chaos is constructive on one level, it can simultaneously be destructive on another, as the sad history of revolutions has amply demonstrated. Who can say what will eventuate? Who knows what rough beast is slouching toward Bethlehem to be born?

I believe one must understand this situation if one is to begin to understand the significance of Donald Trump for religion in America. The question should not be about Trump's private, personal feelings or beliefs. The question is the role of Trump as the defender of the Sacred Canopy of American values and American identity. He is the champion of traditional America, an American Constantine, the Defender of the faith-regardless of how deeply he feels it inside.

\section{Allah or Nothing}

So, a case can be made that America is threatened from within by various forces of confusion and selfish preoccupation. And these paralyzing trends can be understood as softening the country up, making it ripe for conquest, in the short or the long run, by more virulent powers from outside. While we face stiff competition from Russia and China, they do not appear to be bent on destroying Western Civilization. But militant Muslims, the Jihadis and Islamists, freely proclaim this as their goal. But even to acknowledge such a danger is to invite the denunciation of the Politically Correct Orwellians who equate such alarm with 'Islamophobia.' Those who distinguish between 'phobia' (baseless fear of imaginary dangers or people) and legitimate fear of real, if potential, dangers are in effect if not intent fifth columnists for the wouldbe invaders. 'They lead my people astray, saying, 'Peace!' when there is no peace' (Ezekiel 13:10). Donald Trump has sought to control stealthy terrorists from countries rife with them, and his critics claim he is at war with Islam per $s e$. They said the same thing when George W. Bush and even Barack Obama took military measures against the Taliban.

So, are we at war with Islam? Well, any answer is wildly off course which refuses to recognize the plain fact that a radical segment of Islamists understand their own motivation as the conquest of the West and the replacement of our way of life with the iron law of a worldwide Islamic caliphate. This is no mere interpretation by Westerners who may be misreading them; no, very clear statements by Muslims to this effect are on record, and plenty of them. 
They believe themselves to be attacking us in the name and for the sake of Islam. Who are we to say they are wrong about their own motives? Just because that scheme seems as bizarre to us as Charlie Manson's did doesn't mean it doesn't make sense to them. And, unfortunately, it does.

Why are some Westerners so arrogant as to assume these people must really see things as we do? 'It must all be a question of economics and anticolonialism, right?' Don't you get it? It is 'logocentric' and artificial to isolate religion from all of the interlocking social and cultural factors that accompany it. Just because there is an economic aspect doesn't mean the motives of Jihadis are not religious. And just who thinks this? Those who cannot take religion seriously themselves just cannot get inside the heads of those strange (to them) birds who can and do. For all their multicultural pretense, PC Progressives cannot take the otherness of the other very seriously. Believe them, why don't you? They are Muslims heeding the Koranic call to fight and kill infidels. I find this especially ironic: many people believe themselves just too enlightened to suppose we could be facing a religious war. They think that religion couldn't be the real issue, since religion is so silly that no one could possibly take it seriously. But other times they are happy to condemn religion per $s e$ as a poison that is inherently bad. The evil religion does is not just a subset of 'the evil that men do' because of their fanaticism, greed, and intolerance. It is not these vices that are at fault, clad in the trappings of the religion that evil people happen to hold. No, it is the religion itself that is the possessing demon. If reason could cast out religion, some say, then all would be well. When you point out that the same horrors have been perpetrated in the name of atheistic philosophies and regimes, these religion haters will pivot and say that Mao and Stalin were acting in a religious way. Religion equals evil. But in the case of Islam, suddenly it is the other way around. It couldn't be the religion that drives them to the frenzy of murdering men who dare get a Western-style haircut. No, 'It's the economy, stupid!'

Of all people, why are liberal Progressives trying so hard to give these fellows the benefit of the doubt? A Catholic lady demonstrating in front of an abortion clinic? Now that's terrorism. But the Muslim Brotherhood? No worse than a Moose Lodge. I suspect it is a case of cowardly appeasement, what during the Cold War they used to call Finlandization. It is because they know the Catholics are not really dangerous that they can attack them so mercilessly. But those Islamists? They saw people's heads off-on camera! Theirs are clearly the wrong toes to tread on.

\section{Moderate Muslims?}

But what about all those peace-loving Muslims? Aren't they real Muslims, too? Militant Islamists regard them as compromisers who are dropping their obligations in order to coexist with those whom they should hate and overcome. 
They are despised 'liberals' and 'modernists.' It's the sort of abuse theologically liberal Christians have learned to endure from their fundamentalist cousins for generations (though without violence). The more moderate Muslims view themselves just as theological liberals in Judaism and Christianity do. They practice an ancient faith in a modern world where many things have changed, and they have to come to some accord with reality. If militants view moderates as backsliding compromisers, moderates view militants as throwbacks who should get with the program as their religion tries to keep up with a changing world.

We are not fighting against all Muslims, though keep in mind that Sufi scholar Sayyed Hussein Nasr estimates that a mere ten percent of Muslims worldwide support Jihadism. That's a 'mere' hundred million people. It remains true that we are not fighting against all Muslims, because not all Muslims feel their faith requires them to hate and to kill us. But just because we're not fighting against all Muslims doesn't mean we aren't fighting against Muslims. It is not all(ah) or nothing.

I guess this means that we can face the nasty prospect of a war, not on behalf of our religion (especially since 'we' don't have one), but against a religion, radical Islamism. We find it terribly hard to believe this, because we prefer to think we live in a more enlightened age. And we do. The trouble is, they don't.

\section{Reluctant Realizations}

I have taught Religions of the World for some forty years. I once declined to join a secular humanist educational project because their approach toward the religions was shrill and snarky. I couldn't take that approach and retain my scholarly integrity. The first principle of teaching World Religions is to try to represent the religion, each religion, from the inside, as (you imagine) it seems to its adherents. I always assign an essay requiring students to choose one of the religions we cover and imagine how their lives would change if they converted to it. This approach to teaching Comparative Religion tends to incline those who take it to embrace a personal belief that, even with all their differences, the various faiths are all 'true' in some sense. Each seems to do its job for those who practice it. One thus becomes a supporter of all religions, savoring their artistry (including the cognitive artistry of their theologies), their exoticism, and their idioms of spirituality. I have long affirmed this approach, even as an atheist and a humanist. But I am learning to make exceptions.

I doubt even the most liberal Multiculturalist would have defended the murderous Thugee, but the Thugs were wiped out long before the dawn of Multiculturalism. René Girard dared, though one would hardly think it controversial, to condemn the human sacrifice religion of the ancient Aztecs. 
'The terrible sin of ethnocentrism is lying in wait for us and, no matter what exotic societies do, we must guard against the slightest negative judgment... Anti-ethnocentric zeal errs in justifying bloody orgies by accepting the obviously misleading self-image these people present' (Girard 1986: 65). Do we dare condemn modern faiths that perform such atrocities? Are there any?

One need not condemn Satanism; the pulp fiction stereotype is, appropriately, a fiction. Real Satanists are just theatrical humanists, believing in neither god nor devil. But Om Shinrikyo was a nasty bunch, dedicated to clearing the earth of human beings to prepare the way for the return of ancient gods (which also sounds like pulp fiction, but it's not: they pumped Sarin gas into the Tokyo subway system).

Then there are sects that have undeserved bad reputations because of media vilification, like the Unification Church of Sun Myung Moon. (They received the same treatment by the Mainstream media as the Tea Party did.) These folks get slandered for the same reason groups like Om Shinrikyo get ignored or not taken seriously when the issues of religious pluralism and relativism come up. They are not 'our' religions, not mainstream religions with large constituencies that we don't want to offend. But I think these faiths must be factored into the equation.

Think of the parallel situation in party politics. Our Constitution has nothing to say about a two-party system, but it defines democracy as we practice it. There are all kinds of political parties out there, some of which manage to garner enough signatures to make it onto the ballot: Socialist, Progressive Labor, American, Communist, Natural Law, Libertarian, you name it. But they get no air time. Because they receive no coverage, we end up with a skewed view of the democratic system. A high school history teacher of mine once remarked on the irony of our criticizing the Soviet Union for being a one-party state. You could choose from a slate of candidates-all of them Communists. In the USA, you can choose between candidates representing a big two parties. Libertarians make this point all the time, adding that Democrats and Republicans are pretty much one party anyhow.

So is our democracy really what we say it is? Maybe not. Likewise, is our respectable, liberal religious pluralism-relativism what we think it is? Does its apparent viability depend upon a convenient oversimplification? We have to deal the barbaric religions into the game and ask if we can give them all equal honor, as we do Judaism, Buddhism, etc. Because if we had to admit some of them are unacceptable, wouldn't that render invalid the whole 'super-ecumenical respect for everything' (as my Montclair State College professor Steve Johnson called it)? I think it would. I think it does. And it is Islam that has forced me to face this question. For I am thinking more and more that Islam is more like Om Shinrikyo than it is like Christianity or Hinduism. 


\section{Religious Evolution}

Forgive my saying it, but I regard Islam as a religion of barbarism, a selfconfessed death cult, a great step backward in the evolution of religion. It marks a return to the bloodthirsty fanaticism of Joshua and Samuel in Bronze Age Israel. One cannot separate a religion from the culture for which it forms the ideological glue. Islam arose amid scimitar-swinging, slave-trading Arab barbarians. Not to say it simply stopped there. When a religion spreads beyond its cultural cradle, it mutates. It moderates. It begins to shed some of the features that once fit best (or at all) in its original milieu.

This means its members, amid new surroundings, try to assimilate, downplaying (by reinterpreting) the newly offensive aspects of the religion that no one found scandalous back home. You see this, for instance, in Jewish documents from the cosmopolitan Hellenistic world. The Epistle of Aristeas, for instance, written in Greek for Gentiles and assimilating Diaspora Jews, tries to make kosher laws look less silly to outsiders by interpreting them as customs aimed at shielding ancient Israelites from corrosive pagan influences in their environment.

This was probably true, by the way, but to admit it is already an accommodation to intellectual secularism. This is the issue between Pauline and Jewish Christians in the New Testament: the former viewed Torah regulations as Jewish identity markers unnecessary for Gentiles converting to Christianity, while Jewish Christians deemed those 'customs' as the non-negotiable Word of God binding upon all Christians, Jewish or Gentile.

Other Hellenized Jews took it even further, allegorizing ceremonial laws (like the ban on eating mice!) as if they taught moral lessons in some way. Some even thought that, once you understood those lessons, you needn't bother with literal observance. How convenient! Nothing standing in the way of going to that pig-picking in your Gentile neighbors' back yard. 'Sure we're Jews! And, er, darn proud of it. Gimme another shrimp cocktail, will you?' The more you were a good Roman, the more you had to shave from your Judaism. That's the logic of assimilation. And that's why assimilation is such a contentious issue in religions today. Faced with it, some will double down on tradition, since they can see it slipping (or stampeding) away. This is what occasioned the Hasmonean revolt against Jewish cooperation with the Seleucids' Hellenization program. And this accounts for the rise of militant Islam in the world today. It is what anthropologist Anthony Wallace called a Revitalization Movement (Wallace 1956). Diehards for the old ways react to the encroachment of new-fangled notions by mounting a last-gasp effort to turn the clock back and exorcise the influence of foreign, modernizing (and implicitly secularizing) notions.

Once you understand this dynamic of evolution-via-assimilation prompting a recrudescence of the original tradition, you can see the fallacy in one of 
the major arguments of apologists on behalf of both liberal Christianity and moderate Islam. Marty E. Marty refers to what he calls 'the Walter Kaufmann Syndrome.' Kaufmann ruthlessly criticized theologians and clergy, scripture and creeds (Kaufmann 1963). Marty felt Kaufmann was being unfair and trying to make it easy for himself by employing the Fallacy of Bifurcation: he sought to force his readers into eliminating any 'third option' of moderate, reasonable religion, so they'd see the choice as between superstitious stupidity on the one hand and unbelieving rationalism on the other.

Moderates, Kaufmann argued, were just diluting their faith into a 'safe' pretense. Liberal apologists like nineteenth-century theologian Friedrich Schleiermacher tried to launder Christianity to make it acceptable to 'the cultured despisers of religion' (Schleiermacher 1958). Neo-Orthodox theologian and preacher Rudolf Bultmann insisted that the New Testament be demythologized to make Christianity amenable to 'modern man' (Bultmann 1961). You see where this is headed. Conservative Christians like C.S. Lewis mocked this approach as 'Christianity and water' (Lewis 1960: 46). J. Gresham Machen measured the vast distance between historic Christian belief (what Clark H. Pinnock used to call 'classical Christianity') and liberal Protestant Modernism (Machen 1946), concluding that Modernism was Christian in name only (and that it was, in effect, a case of trademark violation). Ultra-liberal theologian Don Cupitt has admitted as much, proposing that 'Christianity is our Old Testament' (Cupitt 1980: xii).

Postmodern apologists for liberal, moderating approaches to religion mount an argument similar to Marty's. They reject what they call an 'essentialist' approach. Who is to say what is 'Christianity proper,' 'true Buddhism,' or 'essential Islam'? They bemoan books like Harnack's What Is Christianity? (in the original German, bearing the same title as Ludwig Feuerbach's The Essence of Christianity). There is no 'essence,' no 'proper' or 'true' version, of Christianity, Islam, Marxism, or anything else. To say that there is, is merely to claim the crown for one's own favorite version.

Today, when Multiculturalist apologists (excuse-makers) for Islam hurl accusations of 'Islamophobia' against anyone who dares to criticize Islam, they try to discount Islamism as a distortion of 'true Islam' (as when Barack Obama insisted that 'ISIS is not Islamic.'). No, they say, 'real' Muslims are gentle folk quietly running falafel stands on your local street corner. This is of course itself an essentialist argument. Consistent essentialists say there simply is no 'true Islam', but this is really saying the same thing: that you can't condemn 'Islam' since there is no such thing. Sure, there are mass-murdering rapists who carry a pocket edition of the Koran in their ammunition belts, but that's pretty much a coincidence. You wouldn't want to 'profile' Muslims as terrorists-or terrorists as Muslims. 
What gives the lie to this nonsense is the dynamic of assimilation-and-reaction. Religions moderate by virtue of assimilation and accommodation. In other words, jettisoning their original principles, no longer being true to themselves. That's the whole point of it.

Moderate Muslims in America are good Americans precisely insofar as they take Islam less seriously. Just read the Koran. Look at Islamic origins and history. When 'moderate Muslims' tell us that jihad has nothing to do with killing infidels but refers only to the pious individual's spiritual struggle, we are hearing either disingenuous spin or hopelessly naïve ignorance.

Consider the claim that Islam is 'the religion of peace.' The word 'Islam' does mean 'peace' but in the sense of 'pacification, submission.' Submission to Allah, which of course means submission to his self-appointed representatives. It's not abstract, but concrete. One might not want to submit to the Islamists. Neither did the people whom the first, founding generation of Muslims conquered. Today's Jihadis are merely returning to the roots of their religion, in contrast to 'moderate' Muslims who have modernized, i.e., compromised, accommodated.

Look where all liberalizing religions inevitably and logically end up: approaching closer and closer to humanism. They increasingly slough off all that once gave them a distinctive character. They come ultimately to see their identity in terms of (sentimental) liberal politics, moral permissiveness, and watered-down beliefs. As far as I can see, from my forty years of study, all that is left to them is 'faith' as permission to ignore the practical results of their favorite policies. Leftist 'people of faith' endorse utopian courses of action, heedless of real-world consequences, since taking them into account would be 'worldly'. Faith means they can be as innocent as doves, but no longer as wise as serpents.

I have come, very reluctantly, to award the title of 'real Islam' to those who howl for the blood of cartoonists, behead passers-by, 'honor-kill' rape-victims, mutilate female genitalia, suicide-bomb Israeli schools, machine-gun people for getting Western haircuts, and so on. These actions are not those of some crazed psychopath who hears his dog commanding him. Instead they are the implications of a creed shared with a great number of co-religionists. The great shame of the decadent West is our pathetic kowtowing to such virulent barbarism.

And here is another sense in which 'Moderate Muslims' are well-assimilated Americans: they are just as cowardly. They have fled the field of the contest for the right to define Islam. They have surrendered the copyright to the Jihadis. Thus, they just don't count. They are like the Germans who, while not actually card-carrying Nazis, knew about the deportation of Jews but raised no note of protest. By their silence, they say, 'It's okay with me.' They have taken the mark of the Great Beast. 
But even these cowards (and secret sympathizers) are not as bad as 'useful idiots' who regard 'Islamophobia' as a greater menace than Islamofascism (which, unlike the former, actually exists).

A few years ago, I was out in Dearborn, Michigan, where I strolled with great interest through a sprawling street fair run by the large local Islamic community. I was (and remain, despite all I have said here) fascinated with Islamic history and theology, and I rejoiced to see the shining pride of these people, showing off the tokens of their heritage. For a long time, the memory of this experience ameliorated my increasing antipathy for Islam. But then I started hearing that some Muslims at one of these fairs stoned a group of (admittedly obnoxious) Christian evangelists. Oh well...

\section{The Isis Cult}

A major blow against our Islamic opposition has been President Trump's military demolition of the caliphate of the Islamic State. Until recently, when I used the term 'Isis cult' I had in mind the once-popular religion of Isis and Osiris, a faith originating in archaic Egypt, then spreading throughout the Roman Empire. It was a major religion when Christianity was just getting started with small groups meeting in local homes. But now, of course, the term refers to the religio-political nightmare known as The Islamic State in Syria (and the Levant). They seek to exterminate Jews, Christians, Yezidis, Shi'ites, and any Sunnis who commit the mortal sin of disagreeing with them. They crucify and behead unbelievers. They rape women and girls, seeing these atrocities as by no means inconsistent with the moral ideals of their religion. They do their best to murder the pre-ISIS past, warring against the cultural heritage of the Middle East and the West, demolishing ancient Assyrian relics and promising to level the Pyramids of Egypt. It is hard to understand such religious and moral perversion, as if these sectarians had prayed the prayer of Gilles de Rais (the historical Bluebeard): 'Evil, be thou my good!'

But it is even harder to understand what motivates young Muslims in America and Western Europe to drop what they're doing and buy a plane ticket to Pandaemonium. In biblical terms, it's as if it was Satan who appeared on the Galilean shore, bidding Peter, Andrew, and the sons of Zebedee to leave their nets and follow him, and they did.

In some ways, there are parallels to the great 'cult' hysteria of the 1970s. Then, too, we heard about seemingly normal young people, none of them particularly disadvantaged, unstable, or uneducated, who walked off good jobs and abandoned degree programs to march to the tune of Reverend Moon, the Hare Krishna sect, the Tony \& Susan Alamo Foundation, the Children of God, etc., etc. Of course, the big difference is that none of these groups was violent. I know what you're thinking: what about Jim Jones and 
the People's Temple? Keep in mind that Jones did not send his people to engage in acts of violence. Politically, the People's Temple was a pretty sophisticated liberal activist group. Their violence was a spasm of self-annihilation. Ditto David Koresh's Branch Davidian commune. The Manson Family, on the other hand, was a genuine exception.

What is a 'cult'? There are two criteria. Neither is necessary, but either is sufficient. Often both are present. First, a cult is a (new) religious movement transplanted from a different culture, e.g., the Unification Church ("Moonies') and the International Society for Krishna Consciousness (a missionary effort of a Hindu devotional (bhakti) sect dating back to fourteenth-century India). Second, there is complete control, voluntarily embraced, over the lives of the adherents, exerted by the leader himself or by a pyramid of deputies if the cult is large enough. Reverend Moon matched and married couples he had never met and who likely did not know each other. (I observed two of their mass weddings in Madison Square Garden.) Jim Jones dissolved married couples and matched them with new mates.

As far as I can tell, none of the notorious cults of the 1970s actually coerced, brainwashed, or forcibly isolated members from their families. These accusations were born of a lack of understanding by outsiders as to what attracted individuals to join these groups and to render such absolute dedication. (Or maybe not so absolute: the typical turnover rate for cults was over 90 per cent.) Concerned parents, pundits, etc., were in effect saying, 'I can't imagine joining a cult unless I got hypnotized or brainwashed!' They just didn't get it, any more than most today can fathom the motivation of young people who up and join ISIS.

But I think it is a mystery with a solution. I believe the late fundamentalist Presbyterian Francis A. Schaeffer hit the bull's eye in his 1972 booklet The New Super-Spirituality (Schaeffer 1972). He was discussing the slightly earlier groups of hyper-fundamentalist Christians like the Alamos and the Children of God. These groups made no secret of their contempt for mainstream Evangelical churches and ministries. The COG, for example, would send into Sunday morning church services their own members clad in sackcloth and ashes, stamping wooden staves on the sanctuary floor, chanting verses of judgment and doom. It was a classic case of a repeating historical pattern described by sociologist Max Weber: sects begin by rejecting 'worldly' religious institutions which have betrayed their founders' radical, counter-cultural vision. But in a generation or so, as these Young Turks have children and assimilate to the societal norms they once repudiated, the sect becomes a church, and after a while the whole thing begins again.

Schaeffer was sectarian in this sense: at some of his lectures (I heard one of them at Princeton University chapel), he would stamp his feet and shout 'We are the true Bolsheviks!' In The New Super-Spirituality, he theorized that 
a new generation of Christian youth, raised on Sunday bombast about taking up one's cross to follow Jesus, were disillusioned by the complacent piety of their pew-potato parents and decided to chuck the affluent American lifestyle and put their money where their mouths were. They sought out Christian communes (I visited some of them: Reba Place Fellowship, Sojourners, Jesus People USA, Christian World Liberation Front), pooled possessions, took Bible names, and spent hours each day witnessing, praying, and reading scripture. All in the advancing shadow of the Second Coming.

I think we are witnessing pretty much the same thing with young Muslims leaving the West and heading for the Islamic State. You have to understand that the whole Jihad movement is a reaction against centuries of theologically devastating Islamic humiliation. In the early centuries Islam ruled an empire larger than the Roman Empire had been at its height. This success could not but be experienced by Muslims as the living confirmation of their belief that they were pioneers and inheritors of the Kingdom of Allah on earth. Thus when their empire began to fade, to fragment, and ultimately to face defeat, even domination, by Christian and secular powers, it was Allah's own reputation that was impeached. It was no mere frustration; it was an existential threat to the religion: 'then your faith is in vain' (1 Corinthians 15:14).

The eventual (and predictable) result was, once again, a Revitalization Movement. When a traditional culture (and thus religion) is threatened by conquest or colonization, many will acquiesce, but some will resist, absorbing elements from the outsiders which had given them a tactical advantage (sometimes including elements of the conquerors' religion, but not necessarily). In short, the partisans of the old ways will try to turn their enemies' weapons against them. This accounts for the happy willingness of Islamists to embrace Western technology like Social Media (not to mention weaponry) to promote a return to the norms of the seventh century.

I believe Islamic young people in the West (some of them) find themselves in the same position as the disappointed Evangelical youth Schaeffer described. What they heard in their mosques about Muhammad and the past glories of Islam sounded antithetical to the pluralism and secularism of the society around them. Pluralism inevitably dissolves any master narrative that may once have given a more monolithic society its identity and sense of direction. For Muslims, their very existence as one more plant in a larger garden seems to contradict the ostensible raison d'être of Islam. The blandishments of radical Islam offer what a secular, pluralistic society cannot give: a jihad to conquer anomie.

Let's return to the question of the mad violence of Islamist militants. What accounts for this? Berger and Luckmann offer the clue to this one. The Islamists, as they know full well, are totally at odds with the modern, secular, religiously diverse world. They face criticism from all sides for their advocacy 
of ancient Shari'ah law. Even the very existence of alternative opinions is perceived as a threat, since the mere fact that other worldviews are possible (and actual) must raise questions: 'They seem pretty convinced, too! How can I be sure we're right?' Traditionally, dogmatic religions try to set their members' minds at ease using 'legitimation' strategies, seeking to defend their distinctive beliefs. They may caricature or slander competing faiths. It might be bad manners, but nobody ends up bleeding (Berger and Luckmann 1967: 108; see also Berger 1969: 27-52).

Evangelism serves as another legitimation strategy. The more people one can persuade to join one's religion, the more votes one can count toward the truth of one's belief (Lofland 1966: 208-209). One's faith is buttressed by one's membership in a 'plausibility structure' (Berger 1969: 42-48) a matrix of people who share one's beliefs, values, and assumptions. The peer support makes the shared beliefs seem self-evidently true. After all, 'everyone' thinks so, right? A believer may seek to keep unbelievers (or other-believers) at arm's length, since at close quarters their lack of faith in your creed might tend to undermine your faith in it. For instance, interfaith marriage is sure to erode either spouse's faith.

The Isis legitimation strategy is in principle the same as evangelism and high-walled parochialism, only it is much fiercer. Here one seeks to remove from the very earth any and all who do not share the true faith. The goal is to make radical Islam seem self-evidently true and impossible to doubt. The very existence of dissenters and doubters constitutes aggression against which the ansaru Allah (helpers of Allah) must defend-by annihilating them. Even the 'pagan' past must go, as Islamists seek to erase any evidence that the world was ever anything but Muslim.

Some politicians urge us to pause a moment and try to understand our enemies. I think I do understand them, and that understanding does nothing to soften my total and complete antipathy to militant Islam. In fact, it only makes it worse.

One point at which ISIS does not parallel the cults of the 1970 s is that business about the turnover rate. The idealistic kids who heed the call of Islamism are not likely to be able to return home once they start having second thoughts.

The theological imagination suggests yet another world-historical role for Donald Trump, as a modern analogue to the Merovingian King Charles Martel, who turned back the Islamic invasion of Europe. Alas, today's Europe is under similar assault but looks to be unequal to the pressing task of rescuing the heritage of Western Civilization in the land of its birth. President Trump, if allowed, might just turn back that tide in America. 


\section{Bibliography}

Barker M (2005) The Older Testament: The Survival of Themes from the Ancient Royal Cult in Sectarian Judaism and Early Christianity. Sheffield: Phoenix Press.

Bellah RN (1980) Varieties of Civil Religion. San Francisco, CA: Harper and Row.

Berger PL (1969) The Sacred Canopy: Elements of a Sociological Theory of Religion. Garden City, NJ: Doubleday Anchor Books.

Berger PL, Luckmann T (1967) The Social Construction of Reality: A Treatise in the Sociology of Knowledge. Garden City, NJ: Doubleday Anchor Books.

Berkhof H (1962) Christ and the Powers, trans. Yoder JH. Scottsdale, AZ: Herald Press.

Bultmann R (1961) New Testament and Mythology. In Bartsch HW (ed) Kerygma and Myth: a Theological Debate. New York, NY: Harper \& Row, pp. 144.

Caird GB (1956) Principalities and Powers: A Study in Pauline Theology. Oxford: Clarendon.

Cupitt D (1980) Taking Leave of God. New York, NY: Crossroad Publishing Company.

Cupitt D (1987) The Long-Legged Fly: A Theology of Language and Desire. Philadelphia, PA: Trinity Press International.

Deleuze G, Guattari F (2009) Anti-Oedipus: Capitalism and Schizophrenia. Baltimore, MD: Penguin Books.

Durkheim E (1965) The Elementary Forms of the Religious Life, trans. Swain JW. New York, NY: Macmillan.

Elliott TG (2005) The Christianity of Constantine the Great. Scranton, PA: University of Scranton Press.

Feyerabend P (1988) Against Method, revised edition. New York, NY: Verso.

Girard R (1986) The Scapegoat, trans. Freccero Y. Baltimore, MD: Johns Hopkins University Press.

Horowitz D (2006) Unholy Alliance: Radical Islam and the American Left. New York, NY: Regnery Publishing.

Kaufmann W (1963) The Faith of a Heretic. Garden City, NJ: Doubleday Anchor Books.

Lewis CS (1960) Mere Christianity. New York, NY: Macmillan.

Lofland J (1966) Doomsday Cult: A Study of Conversion, Proselytization, and Maintenance of Faith. Englewood Cliffs, NJ: Prentice-Hall.

Lyotard JF (1984) The Postmodern Condition: A Report on Knowledge, trans. Bennington G. Minneapolis, MN: University of Minnesota Press.

Machen JG (1946) Christianity and Liberalism. Grand Rapids, MI: Eerdmans.

McGill G (1988) Omen IV: Armageddon 2000. New York, NY: Time Warner Paperbacks. 
Montgomery JW (1975) Principalities and Powers: A New Look at the World of the Occult. New York, NY: Pyramid Publications.

Neusner J (2000) History, Time, and Paradigm in Scripture and in Judaism. Journal of Higher Criticism 7(1): 54-84.

Price RM (2017) Holy Fable, Volume 1: The Old Testament Undistorted by Faith. Valley, WA: Tellectual Press.

Rauschenbusch W (1945) A Theology for the Social Gospel. New York, NY: Abingdon Press.

Richey RE, Jones DG, eds (1974) American Civil Religion. New York, NY: Harper \& Row.

Schaeffer FA (1972) The New Super-Spirituality. Downers Grove, IL: Inter-Varsity Press.

Schleiermacher F (1958) On Religion: Speeches to its Cultured Despisers, trans. Oman J. New York, NY: Harper \& Row.

Wallace AC (1956) Revitalization Movements. American Anthropologist 58(*): 264-281.

Wilson D (1977) Armageddon Now! The Premillenarian Response to Russia and Israel Since 1917. Grand Rapids, MI: Baker Book House. 